\title{
Methodological and Ethical Challenges in Empirical Approaches to Salafism \\ Introduction
}

\author{
Sabine Damir-Geilsdorf \\ Department of Oriental Studies, University of Cologne, Cologne, Germany \\ s.damir-geilsdorf@uni-koeln.de
}

\author{
Mira Menzfeld \\ Department of Religious Studies, University of Zurich, Zurich, Switzerland \\ mira.menzfeld@uzh.ch
}

\begin{abstract}
The special issue "Empirical Approaches to Salafism: Methodological and Ethical Challenges" addresses urgent methodological and ethical issues in qualitative research on Salafism. The contributing authors discuss these in relation to their fieldwork on Salafi beliefs, practices, life courses and world views. The contributions problematize the limits of the usual academic definitions of Salafism by confronting the conventional categories of quietist, political and jihadist Salafism with first-hand field data. Thereby, the authors show how categorial lines begin to blur and to shift when exposed to the ambiguous and dynamic characteristics that are inherent to virtual and real-life fieldwork with Salafis.
\end{abstract}

\section{Keywords}

Salafism - qualitative methods - Islam in Europe - research ethics

Although in recent years Salafism has attracted much scholarly attention, empirical research using methods of participatory observation and qualitative or ethnographic interviews is still rare (Hummel, Kamp, and Spielhaus 2016, 21). As Zoltan Pall and Mohamed-Ali Adraoui $(2018,135)$ conclude, the majority of scholars who deal with Salafism analyse discourses without actually meeting 
and interviewing Salafis. Furthermore, Salafism is a highly politicised research field, dominated by security problems and danger perspectives. This has resulted in numerous scholarly publications that only explore the (very heterogeneous) Salafi groups and movements through the lens of securitisation, while few publications focus on emic perspectives on Salafis and life-world dimensions of individuals.

Similarly, Salafi movements and networks that are categorised as nonpolitical and non-violent, to which the majority of Salafis belong (see, e.g., Wagemakers 2018; Olidort 2015), have been much less examined than those that are considered a security threat. This is understandable, as violent groups attract more public attention and require action more often than nonthreatening groups of religious persons do. However, this biased perspective gives rise to a misconception of the phenomenon of Salafism as a whole: as Jacob Olidort $(2015,1)$ puts it, "if most Salafists globally were involved in forming political parties or in direct violent activity, the world would look very different". The misguided perception of Salafism as necessarily connected to terrorism or extremism has, of course, had a huge impact on research on Salafis as well. Some persons who feel connected to the salafiyya in one way or another reject the label "Salafi" for themselves, for they fear being associated with criminal or terrorist intentions, and many are reluctant to talk to researchers.

Empirical approaches to Salafism that try to step back from security-focused hypotheses and research designs face manifold methodological and ethical challenges. This special issue addresses some of these challenges, based on contributions and discussions that took place during the conference "Empirical Approaches to Salafism in Europe" on 20-21 April 2018, in Cologne, Germany. The authors come from different disciplinary backgrounds and reflect on theoretical, methodological and ethical questions related to their fieldwork with Salafis, in which they used diverse and often mixed empirical approaches ranging from participant observation, qualitative interviews and content analysis to digital media ethnography.

We have identified in the conference contributions, in other scholarly publications on Salafism and in our own fieldwork five main recurrent and repeatedly mentioned challenges as crucial for research on Salafism, which we shall reflect upon in our introduction. They are:1) issues related to labelling persons as "Salafis" in general; 2) the emic and etic politics of labelling and their possible implications; 3) strategies for building trust and gaining access to Salafi interlocutors; 4) reflections on researchers' positions in the field and beyond; and 5) research ethics for protecting personal rights. Many of the challenges subsumed under these five thematic fields are closely connected and decisively 
shaped by the fact that Salafism is increasingly perceived as a security threat. We shall discuss them in the following paragraphs as interrelated issues that every researcher dealing with Salafis most likely has to face-and that require researchers to carefully position themselves before, during and after conducting empirical studies on Salafis.

\section{$1 \quad$ Making (up) Salafis: Questions of Labelling}

An important question that comes up regularly in research with Salafis concerns the decision about whom to include and exclude under the label "Salafi(st)s", and which sublabels may be used to describe interlocutors' religious and ideological positions accurately. Given the heterogeneity of Salafi individuals and movements, and because academic definitions are controversial, this categorisation is by no means easy to determine in research practices. Individuals or movements that were formerly labelled as "Islamist" with further distinguishing adjectives such as "moderate" or "militant", "(Neo) Fundamentalists" or "Jihadists" have now been increasingly subsumed under the umbrella term "Salafi(st)".

Academic definitions of Salafism usually highlight the orientation towards al-salaf al-salih ("the pious ancestors"), i.e. the first generations of Muslims. However, in Sunni Islam the special esteem in which the first three generations are held is not unique to Salafis, because their extraordinary piety is also expressed in the Hadith literature (the transmitted words of the Prophet Muhammad). Most Sunni Muslims would agree to regard al-salaf al-salih as exemplary in belief, religious practice and conduct of life-but this does not by any means make all Sunni Muslims Salafis. What is usually regarded as particular to Salafism is the extremely close adherence to the model of al-salaf al-salih that Salafis strive for and which is not shared by all Sunni Muslims. In a nutshell, according to our best understanding, Salafis assume that emulating these early Muslims by returning to their understanding of Islam and its implementation in all spheres of life leads to a more "authentic" Islam, purified from the "inadmissible innovations" (bida) that they perceive in the present. Among other things, Salafis reject taqlid, the "blind" following of the four canonical schools of law, and attach particular importance to a literal interpretation of the Qur'an and the Sunna (i.e. traditions from the life of the Prophet Muhammad). Key components of Salafi belief are, inter alia, tawhid, i.e. the oneness of God who alone should be worshipped, and al-wala'wa-l-bara', i.e. loyalty to God, Islam and other Muslims and the disavowal of unbelief and persons and actions that would harm Islam. 
However, there are great differences in Salafi views on how Muslims in the idealised period of early Islam would have understood Islam and how religious beliefs should be applied to various areas of life nowadays. This manifests in multiple differences in beliefs and lifestyles as well as religious and political practices that vary significantly not only between different categorised "types" of Salafis, but also between individuals in a given Salafi community.

Referring to Quintan Wiktorowicz (2006), many scholarly works on Salafism distinguish between 1) purist, quietist or apolitical Salafists, 2) political Salafists, and 3) jihadist Salafists. At the same time, scholars have developed various modifications and further subcategories (see Wiedl 2014, 413-416, Nedza 2014, 86-89; Hummel 2014, 100-104; Dantschke 2014, 179ff.; Hummel, Kamp, and Spielhaus 2016, 21ff.; Wagemakers 2017, 2014). These are based on findings that demarcation lines between the three "types" of Salafis can blur, or that, especially since the uprisings in the Arab world, Salafi groups and persons have become more heterogeneous in their views and actions than they were before. Others object that Wiktorowicz's categorization of political and jihadist Salafists relies primarily on Salafism in Saudi Arabia and Afghanistan, whereas Salafism in other regions has seen different trajectories. As Joas Wagemakers $(2017,8)$ has recently stated, there is hardly a conference or workshop on Salafism where scholars do not express their reservations about using Wiktorowicz's categories. He himself, among others, criticises Wiktorowicz's starting point that all Salafis agree on a shared creed but differ over the method of applying it; however, a number of researchers have shown substantial differences between Salafis' definitions of belief and unbelief and their views on when to label a Muslim an unbeliever (ibid., 12f.). For Wagemakers, it is more useful to take into account "what they believe" (ibid., 15) rather than focusing on, for example, their levels of political activism. He elaborates on how analysing the interpretation and application of certain distinct concepts such as al-wala'wa-l-bara' serves a valid revisitation of the definition of Wiktorowicz's three categories, which he nevertheless sees as a "slightly problematic yet ultimately useful tool for the study of Salafism" (ibid., 24).

If one examines more closely interpretations of crucial creedal issues such as definitions of belief and unbelief or al-wala'wa-l-bara', strong boundaries and demarcation lines between different Salafi groups become obvious. This sometimes leads to different factions accusing each other of unbelief (DamirGeilsdorf, Hedider, and Menzfeld 2018). On the other hand, even within a limited spectrum of Salafis, interpretations and applications of certain doctrines can differ significantly because they are always influenced by societal contexts and dynamic interactions between individuals' religious and nonreligious concerns, as well as moral frameworks, experiences and practices. Persons 
sometimes adopt the verdicts of religious authorities they recognise as matching with their everyday lives (Damir-Geilsdorf, Menzfeld, and Hedider 2019; Amin 2019). Since scholarly (sub)categorisations of Salafi individuals often rely on the religious authorities these persons refer to, the question arises of whether persons or groups who are labelled in empirical studies as representatives of certain Salafist currents also speak on behalf of other persons who are considered to belong to the same subcategory of Salafis: who speaks for whom and by whom is authority conferred?

The difficulties laid out by Wiktorowicz (2006) and Wagemakers (2017) in applying the categorisations of Salafism are also addressed in the contribution by Clemens Holzgruber by using the example of two of the most influential Western Salafists, namely the German Pierre Vogel and the Canadian Bilal Philips. Both preachers have been accused by the Islamic State (IS) of being apostates who should therefore be killed. Holzgruber analyses how they distance themselves from Jihadism by (changing) their lines of argument. He argues that Vogel and Philips should be considered primarily as globalised Salafi scholars with a pragmatic approach, who adapt religious doctrines and their applications to diverse and changing contexts. Since they often cross the boundaries of the Salafi types suggested by Wiktorowicz and Wagemakers, placing them in the boxes of these three categories of Salafis in order to describe the positions they hold only makes partial sense. On a more abstract level, Larissa-Diana Fuhrmann and Simone Pfeifer reflect, in their contribution to this special issue, on how they use or avoid the terms "Salafism", "Jihadism" and "Islamism". By describing and comparing different Salafis' biographical narratives, Amir Sheikhzadegan's contribution provides an overview of emically important religious aspects and concepts as well as their application, which gives useful information about what motivates persons to become Salafis - and how this religious orientation is not even necessarily anti-modernist, but possesses, Sheikhzadegan argues, very (post)modern characteristics.

\section{$2 \quad$ Emic and Etic Ways of Labelling}

In the context of determining who should be considered a Salafi, there are also controversial debates in academia over the extent to which self-ascriptions should be taken into account. Many persons categorised as "Salafists" seem to reject the term because of the negative connotation they perceive in the suffix "-ist" or, most importantly, because of the equation of Salafism with terrorism in public discourse. Those who are categorised as "quietist" or "political" Salafis usually reject acts of violence by Jihadist groups and do not want 
to be associated with the perpetrators of these attacks, whom they often do not even regard as Muslims. Some prefer the Arabic terms Salafi for individuals and salafiyya as a group name, while others choose the description ahl al-sunna wa-l-jama'a or insist on the self-ascription "Muslim" without further qualification. Still others refuse to call themselves "Salaf" because this would in their eyes be self-praise for their strength of faith; they often favour formulations such as "I try to follow the path of al-salafal-salih". Since the term "Salafi" often functions as a "mark of exceptionality" (Fadil and Fernando 2015, 77) and is interpreted differently among researchers, interviewees and the apparatus of state security and media outlets, it can become not only a "floating signifier" of doubtful analytical use, but also, as Fuhrman and Pfeiffer argue in this volume, harmful when used as a strategy for Othering.

On the other hand, etic labels do make sense: not only because research needs categorisations to frame its topics, but also because militant groups usually prefer to use "neutral" nouns and adjectives in their names, such as "Islamic" or "Muslim". This serves such groups well in terms of their strategies and ideologies, but does not possess analytical value for describing their very distinct interpretations of recommended religious practices, which are not shared by the overwhelming majority of Muslims. As we can see, one of the major problems with the label Salafism is that subsuming and lumping together seemingly divergent individuals and groups under the same heading - without even considering their own perspectives on themselves - can lead to the equation of totally different groups of believers and a general suspicion that Salafis are a threat to society. At the same time, adopting groups self-labels, regardless of their ideology and religious practice, could even perpetuate a general association of Islam with terrorism, which should be avoided.

Martijn de Koning's contribution strikingly illustrates the intersection of methodological and ethical dilemmas with issues of academic labellings and public (lay) associations with Salafis(m), which emerged during his research on Muslim militant activists in the Netherlands. When some of his interlocutors were prosecuted, he became an expert witness in a trial and was obliged to testify against them. By referring to academic publications, the Public Prosecutor explicitly classified the interlocutors' ideology as Salafism and Jihadism, to mark them as dangerous. The prosecution team also cited an academic publication on the concept of taqiyya "as the way Islamic extremists deceive the West", to assert that the statements and behaviour of the defendants were at odds with the explanations they gave of their ideology throughout the trial. Drawing on his experiences in court, de Koning reflects on how academic knowledge on Salafism and militant activism can be used in a process of categorisation and closure that produces hermetically sealed categories. $\mathrm{He}$ 
argues that works by academics and the category "Salafi" could become part of that security gaze and could willingly or unwillingly contribute to a racialisation, leading to large groups of Muslims being regarded as "a risk" or "at risk" in terms of radicalisation.

Iman Dawood sheds light on intertwinings of self-labelling, etic views on labels, and questions of identity for Salafis. She shows in her contribution to this special issue that there has been a significant change in the desirability of the label "Salafi" within some "Salafi" circles in the UK. Drawing on in-depth interviews conducted with different groupings within the Salafi movement, as well as content analysis of websites, social media pages and audio-visual content of "Salafi" groups and institutions in the UK, she demonstrates that the rejection of the Salafi label has in many cases been an objection to the rise of Salafi Publications and its hegemonic claims over Salafism. Several "Salafi" leaders who formerly referred to themselves as Salafis have now disassociated themselves from this label and refer to their athari 'aqida (athari ${ }^{1}$ creed) rather than salafi 'aqida (salafi creed). Others have stopped using the "Salafi" label and now prefer terms such as "post-Salafi" and "Salafi-Sufi", which can be traced back not only to their distancing themselves from the term's negative connotations but also and even more to changes in their understanding of Islam. Based on her findings, Iman Dawood convincingly highlights the importance of giving attention to our research participants' adoption or rejection of the Salafi label. She stresses that individuals' understanding of Islam is not static and paying attention to whether or not participants use the label, and when they use it, helps to identify ideological differences and important trends within this diverse and constantly evolving Salafi movement.

A fundamental challenge lies in gaining access to a field of research that is strongly politicised and dominated by a security gaze. Against the background of an increasing equation of Salafism with radicalism or even terrorism in public discourse, it is not surprising that many persons are cautious or unwilling to talk to researchers who intend to acquire information about their Salafi beliefs. Potential interlocutors tend to be suspicious of researchers' intentions, trustworthiness, and the financial resources they draw upon. Just as we have experienced this in our own fieldwork, many colleagues who work

1 Refers to the Athariyya, a traditional theological school of the late 8th century that favoured a rather literal interpretation of Qur'an and Hadith. 
on Salafism have reported that they were, for example, suspected of belonging to the secret service. Other interlocutors fear that research on them that labels them as Salafi(st)s might cause them (or even also their families) trouble with authorities, or might lead to their coming under state surveillance. Being monitored by secret services is not unlikely for interlocutors in some cases, depending on the focus of the given research project and the level of data security provided by the research institutions. Interlocutors are sometimes also concerned that they might unwittingly assist in portraying Islam in a negative light. Furthermore, while some persons are eager to get their message out to the public (and thus welcome the researcher as a vehicle for spreading or simply explaining their ideas), others are reluctant to talk to researchers because they fear being quoted incorrectly or out of context.

Building trust and gaining access to the field usually requires longer periods of fieldwork. As the authors of this special issue stress, it is important from the very beginning to disclose the aims and purposes of the research to the interlocutors, and to guarantee anonymity. This transparency and integrity, which is essential to any ethical research practice, is not maintained if one follows the advice of Pall and Adraoui $(2018,140)$, who recommend that it might be "beneficial for one's fieldwork" to show interest when Salafis try to persuade researchers to convert to Islam, because this "gives Salafis further motivation to engage with the academic in the hope that they might direct him or her to the 'right path'". We would argue that such a display of fake intentions leads to an increasingly hermetically closed field and greater distrust of researchers in general, and therefore should not be the research approach of choice. It is, amongst other difficulties, the long-term destructive disabling of further research that, in our opinion, makes this strategy highly unfavourable - not to mention its ethical questionability, which we see as clear here, and which we do not regard as acceptable. Instead, researchers should always inform potential interlocutors about their research foci and intentions, at least with a short oral account of who they are and what they want to know; in times of openly accessible project descriptions and online publishing, false statements and true intentions will become known to the interlocutors anyway.

Fuhrmann and Pfeifer argue that providing transparency (as researchers) and providing anonymity (for interlocutors) are especially important for building relations with interlocutors that possess some level of reliability and mutual trust. This is not only important within offline fieldwork, the authors argue, but is also necessary when conducting research online. It is the responsibility of researchers to remind themselves that their conclusions, hypotheses and opinions may have direct effects on the lives of their interlocutors, who should not experience negative outcomes when they choose to cooperate with 
scholars. At the same time, Fuhrmann and Pfeifer also shed light on the disrespect and refusal of interlocutors not willing to trust researchers at all. Their examples of such cases illustrate rarely discussed experiences that many scholars working with Salafis have to deal with.

\section{Reflecting the Position of the Researcher in the Field}

During the course of research both the researcher and researched persons are potentially vulnerable (Behar 1996). De Koning, for example, describes how his presence at his interlocutors' demonstrations and leisure activities and the fact that he analysed their practices in terms of activism and counter-conduct, rather than terrorism and Salafi-jihadism, was regarded by the public prosecutor as showing that he was too close to them and acting as their apologist. Fuhrmann and Pfeiffer in turn experienced exclusion from research contexts and hostility from potential interlocutors, after having openly stated their affiliations as researchers and social scientists.

While it is useful to reflect on the motivations of interlocutors' participation in research, it is also necessary to reflect on the motivations and biases of the researcher, since academics are not isolated from their socio-political and academic environment. The politicisation of Islam in European countries and the focus on danger perspectives has strongly influenced academic research. The politically contested and securitised field of Salafism, in particular, can influence research by over-stressing one dimension of Salafism to make it easier to explain or to compensate for the danger and security perspective. Since scientific research on this topic tends to have lay recipients in policy and security, researchers might feel more obliged to develop simplistic theoretical frameworks on how to think about Salafism in general, conceptualising it, for example, as being basically separate from religious knowledge and faith-driven conviction, or possibly sketching it rather as a political, ideological or youthcentred movement. Likewise, a heavy focus on literary sources and fatwas (legal opinions) may feed public notions that religious guidelines or preachers' opinions are fixed guidelines for Salafi everyday life. If this view is taken, it appears to be enough to study Salafi sources in order to predict Salafis' mindsets and actions - without acknowledging the heterogeneity of the actual implementation of Salafi belief in practice-but this is, in fact, not sufficient to grasp the phenomenon as a whole.

The position of the researcher in the field, his or her ethnic, cultural, socioeconomic and religious background, and his or her gender and age will influence all fieldwork. Participant observation in particular is always carried out 
in, and produces, a "mode of knowing that depends upon the particular relationship formed by a particular anthropologist with a particular set of people in a particular time and place" (Behar 1996, 5). The researcher's individual characteristics, convictions and hidden biases frame fieldwork and, on the other hand, ideas about a researcher's assumptions, stereotypes and biases that interlocutors develop crucially shape the interaction between researchers and the researched.

For example, interlocutors may address a researcher with a Muslim background differently from the way they address a non-Muslim. Some interlocutors may explain certain aspects of their religious life in a more detailed and comprehensive manner to a Muslim researcher, because they consider his understanding of Islam deeper and less biased than that of a non-Muslim researcher. On the other hand, the reverse may also be true, if interlocutors are trying harder to make the non-Muslim researcher understand their perspective, and thus put more effort into giving a detailed picture about their convictions. Other interviewees, in turn, may tend to refer non-Muslim scientists to "experts" in their community whom they consider better able to explain "correct" beliefs. A person without a religious orientation may well be treated differently from a researcher with a non-Muslim religious orientation. Certain topics may be experienced by male interlocutors as more easily communicated to men (or by female interlocutors to women); and sometimes, non-Muslim female researchers can more easily establish contact with both men and women than male researchers with Salafi women, or female Muslim researchers with Salafi men.

\section{Doing Ethics: Careful Labelling, Protecting Interlocutors' Personal Rights and Maintaining Scientific Autonomy}

As already mentioned in the first two sections above, labels used by researchers not only describe the object of a study, but also produce it (Hummel, Kamp, and Spielhaus 2016). At the same time, categories, labels and research questions cannot be seen as independent from power asymmetries and socially produced epistemological practices (Amir-Moazami 2018, 92f.). Researchers' use of the label "Salafi" and sub-categorisations of various Salafi orientations can contribute significantly to knowledge production about Muslims in general, and to the way Muslims and non-Muslims distinguish between Salafism and "other" or "mainstream" Islam. It may not only (re-)produce essentialising gazes and categories through which Muslims as the "Other" are investigated in an increasing narrowing down of research foci to issues of integration and 
security (Sunier 2014, 1143), but may also imply normative categories that distinguish between a "desirable" and "undesirable" (Salafi) Islam, or between norm and deviation. Persons and groups who are regarded as Salafists or regard themselves as Salafis are influenced by research on themselves, especially since the research results may lead to stigmatisation and criminalisation. This makes it imperative for all researchers to pay extra close attention to their own use of the term "Salafis(m)".

Carolyn Fluehr-Lobban (1998) reminds us that ethics should be reflected upon at every stage of anthropological research. This is the case generally, but especially when it comes to working with interlocutors who may face discrimination by institutions and society as soon as they are labelled "Salafis", and who may, at the same time, sometimes be willing and able to harm other people. Dilemmas, helplessness and ambivalent feelings or impulses within the researcher her-/himself have to be recognised, monitored, and also revealed to provide relevant and reliable field data (Blindt 2009). Ethical questions such as how often to stress one's own role of being a researcher during fieldwork (because the researcher may be seen as a friend over time if he applies techniques of social befriending), how clearly to state he focus of one's research, and what is about to happen to the field data in analysis and publication (Allen 1997), are likely to come up during fieldwork with Salafis. Furthermore, in this context the question arises of how to deal with interlocutors' interference in how their interview data is interpreted and presented by the researcher. If one conducts research that is consciously not only about but also with the researched, it is not always easy to find a balance between one's own scientific independence and the wishes of the researched. Interlocutors-not only in the field of Salafi research, but in general — may even feel betrayed when their perspectives are collected but not adopted by a researcher. It is worth considering one's own professional response to such a situation beforehand, in order to be prepared.

The maxim of "do no harm" to interlocutors, and ensuring their anonymity and privacy, is regarded as essential to ethical conduct in empirical research. However, how this should be achieved is contested within guidelines and regulations, which vary in different disciplines as well as countries. While, for example, ethics review boards are common in the social and cultural sciences in the Anglophone world, in other countries such as Germany there is still a dispute about whether institutionalised principles and procedures are compatible with qualitative research-particularly in explorative ethnographic research where the formulation of the research question is often situationally adapted, and relevant actors in the research field are often not known in advance at all (von Unger, Dilger, and Schönhuth 2016; Bell 2014; Iphofen 
and Tolich 2018). Particularly in the social and cultural sciences, the degree to which codes and guidelines of ethical conduct are binding varies. Informed consent, for instance, has become an essential part of research in anthropology and other disciplines; however, the question of whether or not it needs to be in written form is disputed. Some scholars object that a written form of consent may make people in some fieldwork contexts worry about remaining anonymous (Bell 2014, 2). This may especially apply to interlocutors in the context of "Salafi research". Therefore, it is not only important to constantly reflect on one's own transparency as a researcher in terms of revealing one's goals to interlocutors; it is also important to balance how much transparency the reader or recipient needs in terms of introducing interlocutors, and how much effort towards protection and anonymisation interlocutors should be able to expect. Research on Salafism and with Salafis feeds back into public discourses as well as into the private lives of interlocutors; this has to be remembered at every stage of research.

\section{Concluding Remarks}

With the aim of raising important questions that many researchers working on Salafism are confronted with, we have discussed 1 ) issues of labelling persons as "Salafis" in general; 2) emic and etic politics of labelling and their possible implications; 3) strategies of building trust and gaining access to Salafi interlocutors; 4) reflections on researchers' positions in the field and beyond, and 5) research ethics concerning the protection of personal rights. In fact, separating these categories was undertaken only for structural reasons and reasons of readability; the topic of research ethics in particular is touched on in practically each of the five sections above (and certainly at every stage of research connected with Salafis). When sketching the five-fold prism of challenges that we have just presented, we have tried to reflect the interwoven demands that the field, our fieldwork ethics, our responsibility as researchers and our responsibility for accurate information impose on us-and that everyone working on Salafism should be aware of.

Nadia Fadil and Mayanthi Fernando (2015), reflecting on related issues, remind us that neither imagining an ideologically inflexible framework nor collecting a defined set of rules that would constitute Salafism can make predictable what Salafis actually will (not) do or believe. Rather, even in rigid religious practices, there are always multiple and complex factors that guide an individual's belief and everyday life. How the "moral maze" (de Koning 2013) of living and believing is navigated can only be explored by looking at Salafis 
as individuals, as groups consisting of persons with agency, and as active negotiators of their religion and lifestyle. If this dimension of non-predictable negotiations of Salafi belief is excluded in research, because, for example, nonpersonal Salafi sources are more easily available and analysing written remarks provides a more consistent and static source than looking at Salafi interlocutors themselves, we give space to a simplifying and - in a sensitive fieldmisleading body of knowledge on Salafism, which potentially leads to serious misjudgements. From this point of view, empirical qualitative approaches involving exchange with Salafis $(\mathrm{m})$ —instead of being only about them-also help to guarantee an ethical and balanced view on our field of research.

\section{Acknowledgements}

With many thanks to the Ministry of Culture and Science of the State of North Rhine-Westphalia who funded the conference from which the articles in this special issue are based.

\section{References}

Allen, Charlotte. 1997. "Spies Like Us: When Sociologists Deceive Their Subjects", Lingua Franca 7 (8): 31-39.

Amin, Hira. 2019. "British Muslims Navigating between Individualism and Traditional Authority", Religions 10 (6): 354.

Amir-Moazami, Schirin 2018. "Epistemologien der 'muslimischen Frage' in Europa", in Der inspizierte Muslim. Zur Politisierung der Islamforschung in Europa, edited by Schirin Amir-Moazami. Bielefeld: transcript, 91-124.

Behar, Ruth. 1996. The Vulnerable Observer: Anthropology That Breaks Your Heart. Boston, MA: Beacon Press.

Bell, Kirsten. 2014. "Resisting Commensurability: Against Informed Consent as an Anthropological Virtue", American Anthropologist 116 (3):1-12.

Blindt, Ulrike. 20o9. "Die Frage der Einmischung: Moralische Dilemmata im Feld und die Hilflosigkeit der Ethnologen”, in Feldforschung. Ethnologische Zugänge zu sozialen Wirklichkeiten, edited by Peter Berger, Jeanne Berrenberg, Berit Fuhrmann, Jochen Seebode and Christian Strümpell. Berlin: Weissensee Verlag, 85-117.

Damir-Geilsdorf, Sabine, Yasmina Hedider, and Mira Menzfeld. 2018. "Salafistische Kontroversen um die Auslegung des Glaubens und Alltagspraktiken. Pierre Vogel und andere Akteure in Deutschland", Core Report 2/2018, https://www.connect nrw .de/media/content/Salafistische\%2oKontroversen_o92018.pdf. 
Damir-Geilsdorf, Sabine, Mira Menzfeld, and Yasmina Hedider. 2019. "Interpretations of al-wala' wa-l-bara' in Everyday Lives of Salafis in Germany", Religions 10 (2): 124.

Dantschke, Claudia. 2014. "Lasst Euch nicht radikalisieren!": Salafismus in Deutschland", in Salafismus in Deutschland: Ursprünge und Gefahren einer islamischfundamentalistischen Bewegung, edited by T. G. Schneiders. Bielefeld: Transcript, 171-186.

de Koning, Martijn. 2013. "The Moral Maze: Dutch Salafis and the Construction of a Moral Community of the Faithful", Contemporary Islam 7 (1): 71-83.

Fadil, Nadia, and Mayanthi Fernando. 2015. "Rediscovering the 'Everyday' Muslim: Notes on an Anthropological Divide", HAU_Journal of Ethnographic Theory 5 (2): 59-88.

Fluehr-Lobban, Carolyn. 1998. "Ethics", in Handbook of Methods in Cultural Anthropology, edited by H. Bernard Russell. London: Altamira Press, 173-202.

Hummel, Klaus. 2014. "Salafismus in Deutschland: Eine Gefahrenperspektive neu bewertet", Totalitarismus und Demokratie 11 (2): 95-122.

Hummel, Klaus, Melanie Kamp, and Riem Spielhaus. 2016. "Herausforderungen der empirischen Forschung zu Salafismus: Bestandsaufnahme und kritische Kommentierung der Datenlage", in Salafismus in Deutschland. HSFK Report 1 (2016). Frankfurt am Main: Leibniz-Institut Hessische Stiftung Friedens- und Konfliktforschung.

Iphofen, Ron, and Martin Tolich. 2018. "Foundational Issues in Qualitative Research Ethics", in The Sage Handbook of Qualitative Research Ethics, edited by Ron Iphofen and Martin Tolich. London: Sage, 1-18.

Nedza, Justyna. 2014. "Salafismus: Überlegungen zur Schärfung einer Analysekategorie”, in Salafismus: Auf der Suche nach dem wahren Islam, edited by B. T. Said and H. Fouad. Freiburg im Breisgau: Herder, 80-105.

Olidort, Jacob. 2015. "The Politics of "Quietist' Salafism". Analysis Paper of the Brookings Project on U.S. Relations with the Islamic World. Paper No. 18. https:// www.brookings.edu/wp-content/uploads/2016/o7/Brookings-Analysis-Paper_ Jacob-Olidort-Inside_Final_Web.pdf.

Pall, Zoltan, and Mohamed-Ali Adraoui. 2018. "Interviewing Salafis: Overcoming Fear and Mistrust in Middle Eastern and European Contexts", in Political Science Research in the Middle East \& North Africa: Methodological and Ethical Challenges, edited by Janine A. Clark and Francesco Cavatora. Oxford: Oxford University Press, 135-144.

Sunier, Thijl. 2014. "Domesticating Islam: Exploring Academic Knowledge Production on Islam and Muslims in European Societies", Ethnic and Racial Studies 37 (6): $1138-1155$.

von Unger, Hella, Hansjörg Dilger, and Michael Schönhuth. 2016. "Ethics Reviews in the Social and Cultural Sciences? A Sociological and Anthropological Contribution to 
the Debate", Forum Qualitative Sozialforschung / Forum: Qualitative Social Research, 17 (3), Art. 20, http://nbn-resolving.de/urn:nbn:de:o114-fqs16o3203.

Wagemakers, Joas. 2014. "Salafistische Strömungen und ihre Sicht auf al-wala' wa-l-barac (Loyalität und Lossagung)", in Salafismus: Aufder Suche nach dem wahren Islam, edited by B. T. Said and H. Fouad. Freiburg im Breisgau: Herder, 55-79.

Wagemakers, Joas. 2017. "Revisiting Wiktorowicz: Categorising and Defining the Branches of Salafism", in Salafism after the Arab Awakening: Contending with People's Power, edited by F. Cavatorta, and F. Merone. London: Hurst, 7-24.

Wagemakers, Joas. 2018. "Salafism or the Quest for Purity", Oasis: A biannual journal of cultural inquiry on the relationship between Christians and Muslims in contemporary society 8 (3), https://www.oasiscenter.eu/en/what-is-salafism-quest-for-purity (accessed 11 July 2019).

Wiedl, Nina. 2014. "Außenbezüge und ihre Kontextualisierung und Funktion in den Vorträgen ausgewählter salafistischer Prediger in Deutschland", Working Paper 7. Hamburg: Zentrum für europäische Friedens- und Sicherheitsstudien, Universität Hamburg.

Wiktorowicz, Quintan. 2006. "Anatomy of the Salafi Movement", Studies in Conflict \& Terrorism, 29 (3): 207-23. 